\title{
PENDIDIKAN GENDER DALAM ISLAM: Studi Analisis Nilai-nilai Kesetaraan Gender dalam Pelajaraan PAI di SD Ma'arif Ponorogo
}

\author{
Nanik Setyowati \\ Institut Agama Islam Sunan Giri Ponorogo \\ Email; isnasetyo100585@gmail.com
}

\begin{abstract}
The research that the authors do is focused on the value of gender equality contained in the material of PAI and how to implement it in a learning process. The methode used is descriptive-qualitative. From the research conducted found that 1). There is still a gender bias of men and women who consciously or unconsciously have been presented in the PAI textbooks used in SD 2). Gender Equality in PAI Learning has no learning process or treatment to students outside of gender biased class 3). Teachers' Efforts in Embedding the Value of Gender Equality through learning is To increase insight and raise awareness about gender equality, Action and gender antidiscrimination in PAI learning process and out-of-class activities, Be sensitive to gender issues both in learning and in the use of material books PAI.
\end{abstract}

Keywords: The Value of Gender Equality, Islamic Religious Education

\section{Pendahuluan}

Peran laki-laki dan perempuan secara sosial bukanlah sesuatu yang given dan kodrati. Namun konstruksi peran tersebut sesungguhnya terbentuk oleh budaya dan peradaban yang berkembang dari masa kemasa. Diakui atau tidak, kesenjangan dan ketidakadilan peran antara laki-laki dan perempuan pernah terjadi di panggung sejarah. Bahkan hingga sekarang, kondisi ini masih dapat disaksikan disekitar kita. Dominasi ideologi patriarki yang masih begitu kuat berkembang ditengah masyarakat kita. Patriarki merupakan gambaran kekuasaan laki-laki terhadap perempuan, misalnya dalam keluarga, bapak sebagai kepala atau pimpinan keluarga (Pius, 2001: 576). Hal ini semakin meguntungkan dan menguatkan kedudukan laki-laki dan dengan begitu posisi perempuan lebih banyak dirugikan. Walaupun tatanan sosial ini juga melahirkan ketidakadilan bagi laki-laki dalam beberapa hal namun tidak separah yang dialami kaum perempuan, seperti halnya perdagangan perempuan, kekerasan, dan pelecehan seksual seakan tidak pernah terlewatkan dalam berita-berita kriminal, baik melalui media massa maupun media elektronik.

Menurut golongan konservatif, perempuan hanya sebagai ibu rumah tangga, mendidik anak dan melayani suami, tidak boleh mempunyai aktivitas di luar rumah, karena hal tersebut dalam tugas laki-laki (Huzaemah, 2000: 151). Padahal sejak Al-Qur'an turun telah menghapuskan diskriminasi antara laki-laki dan perempuan. Al-Qur'an memandang sama kedudukan laki-laki dan perempuan, tidak ada perbedaan antara keduanya. Dan dengan tegas Al-Qur'an memandang laki-laki dan perempuan setara dihadapan Allah SWT. Sebagaimana diterangkan dalm surat Al-Hujurat ayat 13 bahwa perbedaan antara laki-laki dan perempuan hanya dari tingkat ketakwaanya. 


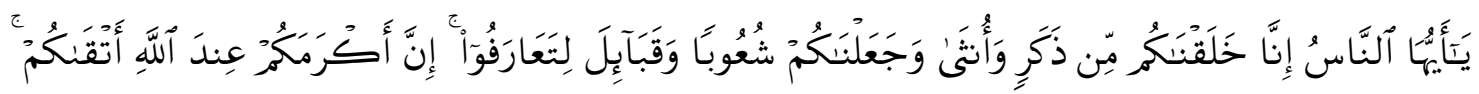

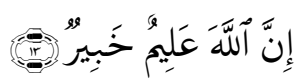

Artinya: Hai manusia, Sesungguhnya kami menciptakan kamu dari seorang laki-laki dan seorang perempuan dan menjadikan kamu berbangsa - bangsa dan bersuku-suku supaya kamu saling kenal-mengenal. Sesungguhnya orang yang paling mulia diantara kamu disisi Allah ialah orang yang paling taqwa diantara kamu. Sesungguhnya Allah Maha mengetahui lagi Maha Mengenal.

Terdapat dua teori peran yang dapat digunakan untuk melihat peran sosial laki-laki dan perempuan. Dua teori tersebut adalah teori nature dan teori nurture. Teori nature adalah teori yang mengandaikan bahwa peran laki-laki dan perempuan merupakan peran yang telah digariskan oleh alam, sedangkan teori nurture adalah teori yang mengandaikan bahwa peran laki-laki dan perempuan merupakan peran yang dikonstruk/dibangun oleh kondisi sosial. Kedua teori peran ini senantiasa berjalan secara berlawanan (Purnomo, 2006: 2).

Namun di antara dua teori tesebut, teori yang kedualah yang dianggap mampu mengungkap problem-problem ketimpangan relasi sosial laki-laki dan perempuan. Walaupun solusi yang ditawarkan oleh teori nurture tidaklah benar sepenuhnya. Sebagai alat analisis teori nurture cukup memiliki peran yang penting. Praktik ketidakadilan gender selama ini muncul dalam bentuk praktik subordinasi dan marginalisasi. Hal ini disebabkan oleh kentalnya ideologi patriarki yang mengakar dalam kehidupan masyarakat. Ideologi ini merupakan faktor determinan yang beroperasi di hampir seluruh segmen kehidupan. Para pejuang perempuan berpandangan bahwa subordinasi perempuan terjadi di semua institusi dan praktik-praktik sosial, dimana kekuasaan laki-laki dan subordinasi perempuan bersifat struktural. Perspektif gender menjadi salah satu bentuk alat analisis untuk menyingkap faktafakta adanya diskriminasi dan perlakuan tidak adil dibalik perbedaan relasi sosial antara lakilaki dan perempuan.

Lembaga sekolah merupakan sarana yang sangat mendukung guna menanamkan nilainilai sosial termasuk nilai-nilai kesetaraan gender pada peserta didik. Selain perlakuan dan hal-hal yang mereka temukan dan mereka rasakan di lingkungan sekolah, penanaman nilai ini juga bisa lewat integrasi pada teks-teks tertulis dalam buku pelajaran. Sebagaimana pernyataan Muawanah dan Hidayah bahwa pendidikan bukan hanya sekedar proses pembelajaran tetapi merupakan salah satu nara sumber bagi segala pengetahuan, karenanya 
ia instrument efektif transfer nilai termasuk nilai yang berkait dengan isu gender (Muawanah, 2006: 65).

Dalam kontek ini, penulis memilih lokasi di SD Ma'arif Ponorogo sebagai objek kajian. SD Ma'arif adalah satu-satunya lembaga sekolah dasar yang berada dibawah binaan LP. Ma'arif Ponorogo. Dengan jumlah warga sekolah yang cukup besar, baik dari jumlah siswasiswi maupun tenaga guru dan karyawan tentu lembaga ini merupakan gambaran masyarakat kecil yang tidak terhindar dari interaksi dan relasi laki-laki dan perempuan.

SD Ma'arif adalah lembaga pendidikan Islam yang mempunyai kurikulum terpadu antara kurikulum DIKNAS dan kurikulum khas lembaga pendidikan Ma'arif yang kental dengan keislaman dan ke-NU-an. Walaupun telah memasukkan berbagai materi keislaman seperti akidah akhlak, fikih, sejarah kebudayaan Islam dalam kurikulumnya, SD Ma'arif juga tetap mengajarkan materi Pendidikan Agama Islam tersendiri secara global. Materi PAI menjadi materi wajib yang harus diberikan kepada peserta didik sebagai ciri identitas lembaga pendidikan Islam. Penulis beranggapan bahwa materi PAI sangat staregis untuk menanamkan nilai kesetaraan gender ini. Penelitian ini dianggap penting guna membahas bentuk penyadaran akan nilai kesetaraan gender di lembaga pendidikan Islam SD Ma'arif ini.

\section{Metode}

Penelitian ini merupakan Qualitative Reseacrh. Dimana bertumpu pada data-data dari lapangan yang kemudian dianalisis. Data yang diperoleh berupa kata-kata, gambar, lambang dan tulisan serta perilaku yang dapat diamati dan dideskripsikan sesuai kebutuhan. Penelitian ini mengambil lokasi di SD Ma'arif Ponorogo yang merupakan salah satu lembaga pendidikan dasar favorit binaan LP. Ma'arif Ponorogo yang terletak di Jl. Sultan Agung No 83A Kelurahan Bangunsari Ponorogo. Teknik pengumpulan data yang digunakan adalah observasi, wawancara, dan dokumentasi. Teknik analisis data dalam penelitian ini menggunakan analisis data kualitatif mengikuti konsep yang diberikan Miles dan Haberman. Miles dan Haberman, mengemukakan aktifitas dalam analisis data kualitatif dilakukan secara interaktif dan berlangsung secara terus-menerus pada setiap tahapan-tahapan penelitian sampai tuntas, dan datanya sampai jenuh. (Matthew, 1992:20).

\section{Hasil dan Pembahasan}

\section{Konsep Gender dalam Al-Qur'an}

Kesetaraan gender adalah kesamaan kondisi bagi laki-laki dan perempuan untuk memperoleh kesempatan dan hak-haknya sebagai manusia, agar berperan dan berpartisipasi dalam kegiatan politik ekonomi, sosial budaya, pertahanan dan keamanan nasional serta 
kesamaan dalam menikmati hasil pembangunan tersebut (Muawanah, 2006: 9). Kesadaran akan kesetaraan gender tersebut harus menjadi wacana publik yang terbuka, sehingga hampir tidak ada sudut kehidupan yang tidak tersentuh wacana ini. Gender telah menjadi perspektif baru yang sedang diperjuangkan untuk menjadi kontrol kehidupan sosial, sejauh mana prinsip keadilan, penghargaan martabat manusia dan perilaku yang sama antar sesama manusia termasuk laki-laki dan perempuan tetapi bukan dalam tataran kodrat.

Di Indonesia yang mayoritas penduduknya muslim, kaum perempuan masih dianggap sebagai kelas dua oleh sebagian masyarakat yang belum memiliki sensitivitas gender (Abd Mustaqim, 2009: 13). Apresiasi terhadap kaum perempuan belum sepenuhnya tercermin dalam pola perilaku masyarakat kita. Padahal Al-Qur'an sebagai kutab suci secara normatif sangat menghargai perempuan sebagaimana ungkapan Abdul Mustaqim, bahwa Al-Qur'an dengan tegas memandang laki-laki dan perempuan adalah setara di hadapan Allah (Abd Mustaqim, 2009: 14). Hal ini terbukti banyak ayat-ayat yang menerangkan tentang kesetaraan laki-laki dan perempuan dalam Islam. Untuk lebih jelas, berikut ini ada beberapa variable kesetaraan yang dapat diidentifikasi, antara lain;

a. Laki-laki dan perempuan sama-sama sebagai hamba.

Islam tidak membedakan antara laki-laki dan perempuan dalam pengabdian. Perbedaan yang dijadikan ukuran untuk memuliakan atau merendahkan derajat mereka hanyalah nilai pengabdian dan ketakwaannya kepada Allah SWT. Dalam Q.S. AdzDzaariyat ayat 56.

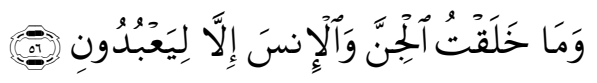

Artinya: Dan Aku tidak menciptakan jin dan manusia melainkan supaya mereka mengabdi kepada-Ku.

b. Laki-laki dan perempuan sama-sama sebagai khalifah di bumi.

Selain sebagai hamba, manusia juga diciptakan untuk menjadi Khalifah yang tunduk dan patuh kepada Allah SWT. Dalam Q.S. Al-An'am 165.
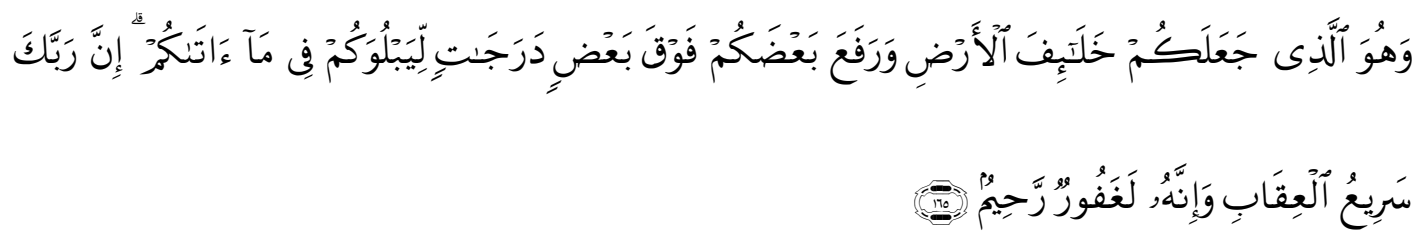

Artinya: Dan dia lah yang menjadikan kamu penguasa-penguasa di bumi dan dia meninggikan sebahagian kamu atas sebahagian (yang lain) beberapa derajat, untuk mengujimu tentang apa yang diberikan-Nya kepadamu. Sesungguhnya 
Tuhanmu amat cepat siksaan-Nya dan Sesungguhnya dia Maha Pengampun lagi Maha Penyayang.

c. Laki-laki dan perempuan sama-sama menerima perjanjian primodial untuk mengakui Tuhan. Keduanya sama-sama mengemban dan menerima amanah perjanjian primodial dengan Tuhan menjelang kelahiran dari rahim ibunya. Dalam Q.S. Al-A'raf ayat 172.

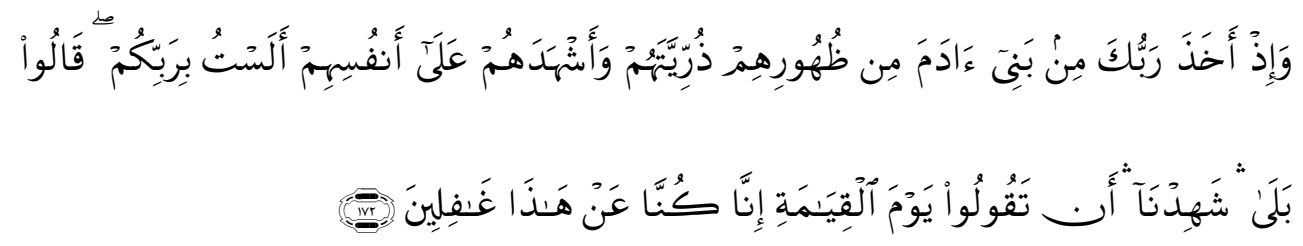

Artinya: Dan (ingatlah), ketika Tuhanmu mengeluarkan keturunan anak-anak Adam dari sulbi mereka dan Allah mengambil kesaksian terhadap jiwa mereka (seraya berfirman): "Bukankah Aku Ini Tuhanmu?" mereka menjawab: "Betul (Engkau Tuban kami), kami menjadi saksi". (Kami lakukan yang demikian itu) agar di hari kiamat kamu tidak mengatakan: "Sesungguhnya kami (Bani Adam) adalah orangorang yang lengah terhadap Ini (ke-Esaan Tuhan)".

Ayat-ayat tersebut sebagai bukti ajaran Al-Qur'an secara normatif dengan tegas memandang laki-laki dan perempuan memiliki kesetaraan yang sama dalam kehidupan individual maupun sebagai anggota masyarakat. Konsep kesetaraan yang ideal tersebut menggambarkan harapan Islam yang besar untuk mewujudkan keadilan dalam segala lini kehidupan manusia baik dalam bidang spiritual maupun karier. Namun kenyataannya masih ada kesenjangan antara normatif (yang semestinya) dan historis (kenyataan).

\section{Gender dalam Konteks Kurikulum PAI}

Kurikulum adalah sejumlah mata pelajaran yang harus ditempuh atau diselesaikan peserta didik untuk memperoleh ijazah. Begitu besar peran yang dikaitkan dengan kurikulum. Kurikulum sangat menentukan dan menjadi ukuran keberhasilan peserta didik. Sejauh mana peserta didik menguasai bahan pelajaran yang disimbolkan dengan angka-angka hasil ujian setiap mata pelajaran. Namun yang tidak kalah penting, apa tujuan yang diharapkan dari ketercapaian sebuah mata pelajaran, karena pengalaman belajar peserta didik akan mempengaruhi perkembangan kepribadiannya. Nilai-nilai apa yang terkandung dalam muatan kurikulum sebuah mata pelajaran, dalam hal ini khususnya mata pelajaran PAI, yang perlu mendapat perhatian khusus, karena sering kali luput dari perhatian pelaku pendidikan.

Nilai-nilai dalam muatan kurikulum PAI menjadi kunci penting untuk mentransfer nilai-nilai ajaran agama Islam yang kemudian akan menentukan kepribadian generasi Islam yang dihasilkan oleh lembaga pendidikan tersebut. Seperti yang dikatakan oleh Hafni Ladjid (2005:26) bahwa Kurikulum PAI merupakan sarana atau alat untuk mencapai tujuan 
pendidikan agama islam yang sekaligus juga arah pendidikan agama dalam rangka pembangunan bangsa dan pembangunan manusia Indonesia seutuhnya.

Pendidikan bukan hanya sekedar proses pembelajaran tetapi merupakan salah satu narasumber bagi segala pengetahuan karenanya merupakan instrument efektif transfer nilai termasuk nilai yang berkaitan dengan isu gender (Muawanah, 2009:65). Gender sebagai bagian dari perkembangan kebudayaan dapat ditransformasikan melalui proses pendidikan di sekolah. Disini akan ditransformasikan nilai-nilai dan norma-norma dalam masyarakat baik secara lugas maupun tersembunyi melalui teks-teks tertulis dalam buku pelajaran maupun dalam perlakuan yang mencerminkan nilai kesetaraan gender yang berlaku.

Bias gender dapat dilihat dalam buku bacaan wajib di sekolah, yang sebagian besar mentransfer nilai atau norma gender yang berlaku dalam kubudayaan sekolah. Artinya sistem nilai gender akan berpengaruh pada kehidupan sistem sosial di sekolah. Sebagai contoh adalah dalam buku ajaran telah dikonstruksi peran gender dan laki-laki secara segregasi, ayah/laki-laki digambarkan bekerja di kantor, di kebun dan sejenisnya (sector public), sementara perempuan/ibu digambarkan di dapur, memasak, mencuci, mengasuh adik, dan sejenisnya (domestik). Indikasi berlangsungnya sosialisasi gender dalam pembelajaran di sekolah jelas terlihat tegas melalui konstruksi tersebut untuk itu perlu perubahan untuk mencapai keadilan dan kesetaraan gender karena berakibat ketimpangan pada salah satu gender khususnya perempuan (Muawanah, 2009:66)

Menurut Zakiah Drajat, Pendidikan Agama Islam tidak mungkin terlepas dari pengajaran agama Islam. Jika penanaman jiwa agama tidak mungkin dilakukan oleh orang tua di rumah, maka harus dilakukan dengan bimbingan seorang guru (Drajat, 1999:108). Maka dengan pengajaran diharapkan akan lebih mudah dalam mentrasfer nilai-nilai Islam yang ada di dalamnya. Nilai keadilan dan kesetaran yang tercover di dalamnya pun akan lebih mudah dicerna dan ditangkap oleh peserta didik dengan perlakuan guru dan sesama teman dalam proses pembelajarannya yang tidak diskriminatif.

Perjalanan panjang gerakan gender masih banyak menemukan pemahaman yang bias terhadap pola relasi gender. Pemahaman yang bias ini akan akan berurat dan berakar pada masyarakat dan pada akhirnya menjadi keharusan dalam tradisi yang terus menerus dikukuhkan. Pemahaman seperti ini akan senantiasa ditrasfer baik melalui media keluarga, pola interaksi dengan lingkungan sekitar maupun melalui media sekolah yang di dalamnya dipengaruhi oleh kondisi nilai dan norma dalam sistem sosial yang sudah mapan, termasuk dalam proses pembelajaran dalam kelas.

Proses pembelajaran melibatkan berbagai komponen yang saling mempengaruhi yakni, tujuan instruksional, materi yang diajarkan, guru, siswa, jenis kegiatan yang dilakukan, 
serta sarana belajar mengajar yang tersedia (Hasibun, 1988:3). Proses pembelajaran merupakan bagian terpenting dalam dunia pendidikan. Proses ini sebagai media transfer dari berbagai misi yang diemban oleh sekolah, termasuk di dalamnya sosialisasi kebudayaan yang berkembang dalam masyarakat. Dalam pelaksanaan program pembelajaran, ada empat langkah pokok yang dilakukan, yaitu evaluasi awal, pelaksanaan pembelajaran, evaluasi akhir, dan tindak lanjut (Ibrahim, 1996:130). Evaluasi awal berfungsi untuk mengetahui kemampuan awal siswa mengenai pelajaran yang bersangkutan, sedangkan evaluasi akhir berfungsi untuk memperoleh gambaran tentang kemampuan yang dicapai siswa pada akhir pelajaran.

Jadi proses pembelajaran tidak semata-mata strategi belajar mengajar yang hanya melibatkan guru dan murid, melainkan seluruh aktifitas untuk mencapai tujuan belajar dengan melibatkan semua komponen belajar mengajar baik secara langsung dan tidak langsung. Dan yang lebih penting lagi bahwa proses belajar mangajar merupakan media yang utama guna untuk mentrasfer nilai-nilai kebudayaan yang berkembang dalam masyarakat, termasuk di dalamnya adalah nilai kesetaraan gender.

Berkaitan dengan fungsi dari PAI dalam penanaman nilai kesetaraan gender, maka dalam kegiatan pembelajaran PAI ada enam pendekatan yang digunakan, yaitu: pertama, pendekatan rasional, yaitu suatu pendekatan dalam proses pembelajaran yang lebih menekankan kepada aspek penalaran. Kedua, pendekatan emosional, yaitu upaya menggugah perasaan (emosi) anak didik dalam menghayati perilaku yang sesuai dengan ajaran agama dan budaya bangsa. Ketiga, pendekatan pengalaman, yaitu memberikan dan menciptakan kesempatan kepada anak didik untuk mempraktikkan ajaran agama yang telah dipelajarinya. Keempat, pendekatan pembiasaan, yaitu memberikan kesempatan kepada peserta didik untuk bersikap dan berperilaku sesuai dengan ajaran Islam dan budaya bangsa dalam menghadapi beragam persoalan kehidupan. Kelima, yaitu pendekatan fungsional, yaitu menyajikan materi pembelajaran yang memiliki nilai manfaat secara nyata bagi kehidupan anak didik. Keenam, yaitu pendekatan keteladanan, yaitu guru, kepala sekolah,seluruh staf, orang tua dan juga masyarakat memberikan suri tauladan kepada anak didik (Naim, 2007:75).

\section{Analisis Nilai Kesetaraan Gender dalam Teks Materi PAI}

Nilai-nilai dalam muatan kurikulum PAI menjadi kunci penting untuk mentransfer nilai-nilai agama Islam, yang kemudian akan menentukan kepribadian generasi Islam yang dihasilkan oleh lembaga pendidikan tersebut. Seperti yang dikatakan oleh Hafni Ladjid bahwa Kurikulum PAI merupakan sarana atau alat untuk mencapai tujuan pendidikan agama Islam 
yang sekaligus juga arah pendidikan agama dalam rangka pembangunan bangsa dan pembangunan manusia Indonesia seutuhnya (Hafni, 2005:26).

Penelitian terhadap teks materi pelajaran PAI yang disusun oleh Tim KKG-PAI kabupaten Ponorogo yang sesuai standart isi kurikulum 2016 (KTSP), adalah untuk melacak bias gender yang ada didalam teks-teks pelajaran ini sehingga mampu melihat ketimpangan gender yang ada dalam buku tersebut dan akhirnya menjadi tugas pembaca terutama para pendidik untuk lebih sensitif terhadap bias gender dalam pelajaran-pelajaran yang diajarkan.

Usaha untuk mewujudkan idealitas pendidikan Islam, sebagaimana dirumuskan oleh para ahli sangat dipengaruhi oleh faktor pendidik. Pendidik harus memiliki rasa kemanusiaan yang mendalam (Sutari, 1982:18). Wawasan pendidik yang cukup tentang kesetaraan gender akan sangat mempengaruhi kemana arah pendidikan sekolah tersebut akan diarahkan sesuai ideologi dan wawasan yang dimiliki. Dengan demikian, akan lebih merangsang sensivitas gender dalam membaca pesan nilai gender yang tertuang dalam sebuah teks meteri pelajaran melalui rumusan kalimat, penokohan, gambar, kisah-kisah teladan, maupun pembagian kerja dan kategori lain yang sensitive gender.

Dari hasil analisis teks yang dilakukan penulis ditemukan beberapa bias gender laki-laki dan perempuan yang secara sadar maupun tidak sadar telah dihadirkan dalam buku materi pelajaran PAI ini. Disini terdapat porsi yang belum seimbang yang berimplikasi pada dominasi peran seperti penentuan contoh nama atau figur yang digunakan terdapat $79,4 \%$ nama laki-laki dan 20,5\% nama perempuan. Dominasi gambar laki-laki 93,8\% dan gambar perempuan 6,2\%. Sedangkan tokoh laki-laki yang dimunculkan 96,4\% dan tokoh perempuan hanya 3,6\% saja. Kisah laki-laki teladan sebanyak $90 \%$ dan kisah perempuan teladan $10 \%$. Dalam kategori kepemimpinan yang didominasi oleh tokoh-tokoh laki-laki, diperkuat lagi dengan tidak dimunculkannya satu pun sosok perempuan yang menjadi pemimpin. Mayoritas setiap kategori didominasi oleh laki-laki dengan prosentase di atas $90 \%$. Dapat menyimpulkan bahwa perempuan terkesan lemah dan selalu dalam posisi kalah.

Dalam pelajaran PAI Ketimpangan tersebut terlihat dari segi pemunculan tokoh, nama, kisah yang didominasi oleh kaum laki-laki yang seharusnya meletakkan laki-laki dan perempuan dalam posisi dan frekuensi yang seimbang, sehingga akan merubah sedikit demi sedikit paradigma patriarkhi yang telah menjadi budaya di lingkungan masyarakat. Dengan demikian nilai kesetaraan yang menjadi misi pendidikan sebagai transfer of value tersebut benar-benar teraplikasikan dalam proses pembelajaran.

Dalam hal pembagian kerja dan pemberian kesempatan bagi laki-laki dan perempuan, dalam buku kelas I, ada yang menyebutkan peran yang sama antara laki-laki dan perempuan, misalnya dengan penyebutan keduanya dalam objek perintah suatu materi 
pelajaran, namun juga ditemukan beberapa kalimat yang secara eksplisit menyebutkan pembagian peran yang berbeda dan alami antara keduanya. Dalam buku kelas III, tidak ditemukan kalimat yang menerangkan peran laki-laki dan perempuan secara khusus, semua kegiatan dan perintah ditujukan secara umum. Berbeda dengan buku PAI kelas V, sebenarnya tidak ditemukan pembagian kerja secara khusus antara laki-laki dan perempuan, tetapi kecenderungan kemunculan laki-laki yang mendominasi di ruang publik mengiaskan bahwa perempuan selalu berperan di balik layar dan hanya berkiprah dalam ranah domestik.

Adanya anggapan bahwa kaum perempuan memiliki sifat memelihara dan rajin serta tidak cocok untuk menjadi kepala rumah tangga, berakibat bahwa semua pekerjaan domestik rumah tangga menjadi tanggung jawab perempuan. (Munji, 2007) Dalam buku yang menjadi objek penelitian, tidak menunjukkan kesenjangan yang mencolok dalam pembagian kerja, susunan kalimat yang digunakan tertuju pada kedua-duanya tanpa mempertimbangkan status gender yang disandang masing-masing.

Anggapan bahwa laki-laki lebih kuat, lebih cerdas, dan emosional, lebih stabil, sementara perempuan lemah, kurang cerdas dan emosinal, kurang stabil hanyalah stereotipe gender. Para feminis menunjuk beberapa faktor yang dianggap sebagai agen pemasyarakatan (agent of civilization) stereotip gender, antara lain susana keluarga, pendidikan, kehidupan ekonomi dan susana sosial politik. (Munji, 2007) Stereotipe ini berakibat wajar sekali bila pendidikan kaum perempuan dinomorduakan. Banyak peraturan pemerintah, aturan keagamaan, kultur dan kebiasan masyarakat yang dikembangkan karena stereotipe tersebut.

Namun dengan wawasan para pendidik yang berkembang, diharapkan mampu menetralisir bias gender yang masih terdapat dalam buku PAI yang digunakan. Wawasan pendidik akan sangat berpengaruh pada implementasi sebuah kurikulum dan materi dalam sebuah proses pembelajaran dan bagaimana materi PAI yang lelah disusun dalam sebuah buku dituangkan dalam pembelajaran dikelas untuk menanamkan nilai-nilai kesetaraan gender pada peserta didik.

\section{Integrasi Nilai Kesetaraan Gender dalam Pembelajaran PAI}

Dalam konteks pembelajaran Pendidikan Agama Islam (PAI), tujuan pembelajarannya adalah bagaimana anak didik dapat memahami dan mengerti terhadap ajaran-ajaran Islam yang menjadi topik bahasan (kognitif), kemudian dari pemahaman ini para peserta didik dapat mengintroduksi menjadi bagian dari sikap dan nilai dalam kehidupan sehari-hari (afektif), dan peserta didik memiliki ketrampilan yang berkaitan dengan pelajaran tersebut (Ngainun, 2007:69). Dengan demikian pembelajaran PAI merupakan sebuah rekayasa yang diupayakan untuk membantu peserta didik tumbuh dan berkembang sesuai maksud dan tujuan yang telah disusun. 
Pendidikan bukan hanya sekedar proses pembelajaran tetapi merupakan salah satu narasumber bagi segala pengetahuan, karenanya ia merupakan instrument efektif untuk transfer nilai termasuk nilai yang berkait dengan isu gender (Muawanah, 2006:65). Gender sebagai bagian dari perkembangan kebudayaan juga ditrasformasikan melalui proses pendidikan di sekolah. Disini akan ditransformasikan nilai-nilai dan norma-norma dalam masyarakat baik secara lugas maupun tersembunyi melalui teks-teks tertulis dalam buku pelajaran maupun perlakuan dalam sebuah proses pembelajaran yang mencerminkan nilai kesetaraan gender yang berlaku.

Berdasarkan pendapat para informan tentang gender dan implementasinya dalam pembelajaran, menurut pengamatan mereka selama ini tidak ada proses pembelajaran atau perlakuan kepada siswa di luar kelas yang bias gender. Walaupun buku PAI yang digunakan oleh para guru PAI banyak terdapat bias gender, namun mereka mampu mentransfer dan menanamkan nilai-nilai kesetaraan tersebut dengan perlakuan yang sensitif gender dan kesadaran akan pentingnya nilai kesetaraan tersebut harus ditanamkan pada jiwa peserta didik.

Jumlah peserta didik SD Ma'arif Ponorogo 799 anak yang terdiri dari 55.1\% laki-laki yaitu 440 siswa, dan $44.9 \%$ perempuan yaitu 359 siswi. Dengan perbedaan jumlah yang mayoritas adalah siswa laki-laki untuk tidak mendiskriminasi kepada pihak minoritas yang di sini adalah perempuan. Sebagaimana keterangan para guru PAI bahwa mereka tidak pernah membedakan perlakuan mereka berdasarkan perbedaan laki-laki dan perempuan. Semua siswa diberi kesempatan yang sama untuk berlomba dalam berprestasi. Begitu juga dalam pembelajaran di kelas, para guru memperlakukan para peserta didik berdasarkan prestasi dan potensi yang dimiliki bukan karena laki-laki atau perempuan. Walaupun dengan jumlah yang lebih sedikit, para guru di SD Ma'arif memberi kesempatan yang sama kepada keduanya dalam porsi yang sama.

Anggapan bahwa laki-laki lebih kuat, lebih cerdas, dan emosional, lebih stabil, sementara perempuan lemah, kurang cerdas dan emosinal, kurang stabil hanyalah stereotipe gender.(Munji, 2007) Anggapan ini sepertinya tidak berlaku dalam lingkungan SD Ma'arif Ponorogo, karena tidak sedikit anak perempuan yang justru memiliki kemampuan lebih dari pada anak laki-laki, dan terbukti dalam keikutsertaan beberapa peserta lomba yang mayoritas adalah anak perempuan. Demikian juga berdasarkan keterangan beberapa guru bahwa juara kelas kebanyakan diraih oleh perempuan. Hal ini menunjukkan stereotip yang ditujukan kepada para perempuan sudah mulai tergeser dalam lembaga pendidikan SD Ma'arif ini.

\section{Upaya Guru dalam Integrasi Nilai Kesetaraan Gender melalui Pelajaran PAI}


Guru mempunyai peran yang sangat penting dalam membangun kesadaran siswa terhadap nilai-nilai kesetaraan gender dan sikap anti diskriminasi terhadap kaum perempuan di sekolah. Penanaman ini dapat dimulai dari proses transformasi nilai dalam sebuah pembelajaran. Agar tercapai tujuan yang diharapkan, para guru terutama Guru PAI SD Ma'arif telah mempersiapkan diri dan beraksi dengan upaya-upaya berikut:

1. Menambah wawasan dan meningkatkan kesadaran yang tinggi tentang kesetaraan gender. Seorang guru seharusnya mempunyai wacana dasar yang cukup tentang kesetaraan gender. Dengan wacana yang cukup tentang kesetaraan gender seorang guru diharapkan mampu untuk bersikap adil dan tidak diskriminatif terhadap peserta didik perempuan maupun laki-laki.

2. Bertindakan dan bersikap anti diskriminasi gender. Dalam hal ini, tindakan dan sikap para guru dalam proses pembelajaran maupun kegiatan di luar kelas, mereka memberi kesempatan dan memperlakukan peserta didik tanpa membedakan laki-laki maupun perempuan. Pertimbangan yang mereka gunakan hanya berdasarkan kemampuan dan prestasi yang dimiliki para siswa baik laki-laki maupun perempuan.

3. Bersikap sensitif terhadap permasalahan gender. Seorang guru harus sensitif dalam melihat adanya diskriminasi dan ketidakadilan gender, di dalam maupun diluar kelas. Dalam menyikapi materi PAI yang disusun oleh TIM KKG PAI Ponorogo yang masih banyak terdapat teks yang bias gender, para guru PAI telah melakukan penyadaran dan penanaman nilai kesetaraan tersebut secara umum kepada para siswa dalam proses pembelajaran. Para guru SD Ma'arif terutama guru PAI telah mempunyai sensifitas yang tinggi dalam menangkap permasalahan gender dalam dunia pendidikan. Kesadaran mereka telah mulai terbangun dalam menanamkan sensifitas gender ini kepada peserta didik, terutama pembelajaran PAI.

\section{Kesimpulan}

Nilai Gender dalam Teks Materi Pendidikan Agama Islam (PAI) di SD Ma'arif Ponorogo, sesuai hasil analisis teks yang dilakukan penulis ditemukan beberapa bias gender laki-laki dan perempuan yang secara sadar maupun tidak sadar telah dihadirkan dalam buku materi pelajaran PAI ini. Disini terdapat porsi yang belum seimbang yang berimplikasi pada dominasi peran seperti penentuan contoh figur atau nama, penentuan tokoh teladan, penentuan kisah-kisah yang ditampilkan, aspek kepemimpinan, pembagian kerja dan pilihan profesi.

Kesetaraan Gender dalam Pembelajaran PAI di SD Ma'arif Ponorogo, berdasarkan pendapat para informan tentang gender dan implementasinya dalam pembelajaran, menurut 
pengamatan mereka selama ini tidak ada proses pembelajaran atau perlakuan kepada siswa diluar kelas yang bias gender. Walaupun buku PAI yang digunakan oleh para guru PAI banyak terdapat bias gender, namun mereka mampu mentransfer dan menanamkan nilai-nilai kesetaraan tersebut dan kesadaran akan pentingnya nilai kesetaraan tersebut harus ditanamkan pada jiwa peserta didik.

Upaya yang dilakukan Guru dalam Menanamkan Nilai Kesetaraan Gender melalui pembelajaran PAI di SD Ma'arif Ponorogo adalah:

a. Menambah wawasan dan meningkatkan kesadaran tentang kesetaraan gender.

b. Bertindakan dan bersikap anti diskriminasi gender dalam proses pembelajaran PAI maupun kegiatan diluar kelas.

c. Bersikap sensitif terhadap permasalahan gender, baik dalam pembelajaran maupun dalam penggunaan buku materi PAI.

\section{Acknowledgement}

Penelitian ini diaksanakan dengan dana mandiri. Dengan terlaksananya penelitian ini peneliti mengucapkan terimakasih kepada Lembaga Penelitian dan Pengabdian Masyarakat (LP2M) yang telah memberi dukungan penuh secara administratif dari awal sampai terpublikasinya hasil penelitian ini, tidak lupa saya ucapkan terimakasih kepada kepala sekolah SD Ma'arif Ponorogo yang telah memberikan kesempatan untuk meneliti lembaga pendidikan yang beliau pimpin serta kepada seluruh pihak yang telah membantu secara langsung maupun tidak langsung dala proses penyusunan hasil penelitian ini.

\section{Referensi}

Drajat, Zakiah. (1999). Perkembangan psikologi Agama dan Pendidikan Islam di Indonesia. Ciputat: Logos Wacana Ilmu.

Hasibun. (1988). Proses Belajar Mengajar. Bandung: Remaja Karya.

Ibrahim. (1996). Perencanaan Pengajaran. Jakarta: rineke Cipta.

Ladjid, H. (2005). Pengembangan Kurikulum. Ciputat: Quantum Teaching.

Mustaqim, A. (2008). Paradigma Tafsir Feminis; Membaca Al-Qur'an dengan Topik Perempuan. Yogyakarta: Logung Pustaka.

Purnomo, A. (2006). Teori Peran Laki-laki dan Perempuan. Malang: UIN Malang.

Tahido, H. (2000). Membincang Feminisme: Diskursus Gender Perspektif Islam. Surabaya: Risalah Gusti.

M. Ainiul Yaqin, Pendidikan Multikultural Cross-Cultural Understanding untuk Demokrasi dan Keadilan, (Yogyakarta : Nuansa Aksara, 2005), Cetakan Pertama. 
Mansour Fakih. (1996). Analisis Gender dan Transformasi Sosial. Yogyakarta: Pustaka Pelajar.

Muawanah, Hidayah. (2006). Menuju Kesetaraan Gender. Malang: Kutub Minar.

Ngainun Naim, Achmad Patoni. (2007). Materi Desain Pembelajaran Pendidikan Agama Islam (MPDP PAI). Yogyakarta: Pustaka Pelajar.

Pius a Partanto dan M. Dahlan Al-Barry. (2001) Kamus Ilmiah Populer. Yogyakarta: Arkola.

Sutari Imam Barnadib. (1982). Pengantar Ilmu Pendidikan Sistematis. Yogyakarta: Fakultas Ilmu pendidikan (FIP) IKIP Yogyakarta. 